\title{
The Influence of Erythrocyte Maturity on Ion Transport and Membrane Lipid Composition in the Rat
}

\author{
M. VOKURKOVÁ ${ }^{1}$, H. RAUCHOVÁ ${ }^{1}$, Z. DOBEŠOVÁ ${ }^{1}$, J. LOUKOTOVÁ ${ }^{1}$, \\ O. NOVÁKOVÁ ${ }^{2}$, J. KUNEŠ ${ }^{1}$, J. ZICHA ${ }^{1}$
}

${ }^{1}$ Institute of Physiology of the Czech Academy of Sciences, Prague, Czech Republic, ${ }^{2}$ Department of Animal Physiology and Developmental Biology, Faculty of Sciences, Charles University, Prague, Czech Republic

Received February 16, 2016

Accepted March 8, 2016

\section{Summary}

Significant relationships between ion transport and membrane lipid composition (cholesterol, total phospholipids and sphingomyelins) were found in erythrocytes of salt hypertensive Dahl rats. In these animals mean cellular hemoglobin content correlated negatively with $\mathrm{Na}^{+}-\mathrm{K}^{+}$pump activity and $\mathrm{Na}^{+}$leak but positively with $\mathrm{Na}^{+}-\mathrm{K}^{+}$cotransport activity. Immature erythrocytes exhibit lower mean cellular hemoglobin content (MCHC) than mature ones. The aim of the present study was to find a relationship between erythrocyte maturity, membrane lipid composition and ion transport activity in Wistar rats aged three months which were subjected to repeated hemorrhage (blood loss $2 \mathrm{ml} /$ day for 6 days) to enrich circulating erythrocytes with immature forms. Immature and mature erythrocyte fractions in control and hemorrhaged rats were separated by repeated centrifugation. Hemorrhaged rats had increased number of reticulocytes but reduced hematocrit and $\mathrm{MCHC}$ compared to control rats. Immature erythrocytes of hemorrhaged rats differed from mature ones of control animals by elevated $\mathrm{Na}^{+}-\mathrm{K}^{+}$pump activity, reduced $\mathrm{Na}^{+}-\mathrm{K}^{+}$cotransport activity and increased $\mathrm{Rb}^{+}$ leak. These ion transport changes in immature erythrocytes were accompanied by higher concentration of total phospholipids in their cell membranes. Membrane phospholipid content correlated positively with $\mathrm{Na}^{+}-\mathrm{K}^{+}$pump activity and cation leaks but negatively with $\mathrm{Na}^{+}-\mathrm{K}^{+}$cotransport activity. Moreover, they were also negatively related with $\mathrm{MCHC}$ which correlated negatively with $\mathrm{Na}^{+}-\mathrm{K}^{+}$pump activity and $\mathrm{Rb}^{+}$leak but positively with $\mathrm{Na}^{+}-$ $\mathrm{K}^{+}$cotransport activity. Thus certain abnormalities of erythrocyte ion transport and membrane lipid composition detected in hypertensive animals might be caused by higher incidence of immature cells.

\section{Key words}

Reticulocytes - Immature erythrocytes - Mean cellular hemoglobin content $-\mathrm{Na}^{+}-\mathrm{K}^{+}$pump $\bullet \mathrm{Na}^{+}-\mathrm{K}^{+}$cotransport $\bullet$ $\mathrm{Na}^{+}$leak $-\mathrm{Rb}^{+}$leak - Membrane phospholipids - Membrane cholesterol

\section{Corresponding author}

M. Vokurková, Institute of Physiology of the Czech Academy of Sciences, Videnska 1083, 14220 Prague 4, Czech Republic. Fax: +420 24106 2488. E-mail: martinavokurkova@seznam.cz

\section{Introduction}

Growing and/or proliferating cells change not only their morphology but also their function. Vascular smooth muscle cells are a good example because mature cells with contractile phenotype might dedifferentiate into the cells with synthetic phenotype which are characterized by reduced contractility, altered response to various vasoactive agents, abnormal cell calcium handling and different changes of receptors, ion transporters and intracellular signaling pathways (Matchkov et al. 2012, Misárková et al. 2016). There is increasing evidence that such pronounced changes can also be found during the maturation of human or rat erythrocytes.

Immature human erythrocytes, which are enhanced in the circulation e.g. during anemia of various origin, have lower mean cellular hemoglobin content (MCHC), increased $\mathrm{K}^{+}$content and augmented activity of the $\mathrm{Na}^{+}-\mathrm{K}^{+}$pump and reduced activity of the $\mathrm{Na}^{+}-\mathrm{K}^{+}$ 
cotransport in comparison with mature erythrocytes (Hentschel et al. 1986, Engelmann et al. 1990a). Repeated blood donations increased erythrocyte $\mathrm{K}^{+}$ content and enhanced the activities of multiple transport systems such as $\mathrm{K}^{+}-\mathrm{Cl}^{-}$cotransport, $\mathrm{Na}^{+}-\mathrm{Li}^{+}$ countertransport or $\mathrm{Na}^{+}-\mathrm{K}^{+}$pump, whereas this was not the case for $\mathrm{Na}^{+}-\mathrm{K}^{+}-2 \mathrm{Cl}^{-}$cotransport system (Brugnara et al. 1993). $\mathrm{K}^{+}-\mathrm{Cl}^{-}$cotransport activity, which is responsible for volume reduction of reticulocytes, is also enhanced in immature erythrocytes of healthy humans (Brugnara and Tosteson 1987) or patients with sickle cell anemia (Canessa et al. 1987, Etzion et al. 1996, Quarmyne et al. 2011).

The enhanced activity of $\mathrm{Na}^{+}-\mathrm{K}^{+}$pump was also demonstrated in immature sheep and pig erythrocytes and this activity decreased during in vitro maturation of these cells (Blostein et al. 1983, Lauf et al. 1984). Potassium turnover is also markedly enhanced in rat reticulocytes, both influx and efflux rates being approximately threefold increased compared to mature cells. The enhanced $\mathrm{K}^{+}$ accumulation in reticulocytes can be attributed to the increased number of $\mathrm{Na}^{+}-\mathrm{K}^{+}$pump units which are qualitatively identical to those of mature cells (Furukawa et al. 1981). Moreover, Mäirbaurl et al. (2000) demonstrated that enhanced $\mathrm{Na}^{+}-\mathrm{K}^{+}$pump activity and augmented ouabain- and bumetanide-insensitive $\mathrm{Na}^{+}$leak decreased during in vitro maturation of rat reticulocytes. Finally, Ihrig et al. (1992) reported a progressive agedependent reduction of ouabain-sensitive $\mathrm{K}^{+}$influx mediated by $\mathrm{Na}^{+}-\mathrm{K}^{+}$pump in erythrocytes of Wistar rats between the $11^{\text {th }}$ and $19^{\text {th }}$ week of their age, whereas bumetanide-sensitive $\mathrm{K}^{+}$influx mediated by $\mathrm{Na}^{+}-\mathrm{K}^{+}$ cotransport moderately increased in the same age period. Our previous study in Dahl rats (Zicha and Duhm 1990) reported decreased MCHC and very high $\mathrm{Na}^{+}-\mathrm{K}^{+}$pump activity due to the augmented $\mathrm{Na}^{+}$leak in a subgroup of anemic salt hypertensive animals. Furthermore, we showed significant relationships between erythrocyte ion transport and membrane lipid composition in Dahl rats with salt hypertension in which MCHC correlated negatively with activity of the $\mathrm{Na}^{+}-\mathrm{K}^{+}$pump and $\mathrm{Na}^{+}$leak and positively with activity of the $\mathrm{Na}^{+}-\mathrm{K}^{+}$cotransport (Vokurková et al. 2005).

It should be kept in mind that the changes in membrane lipid composition might considerably modify $\mathrm{Na}^{+}$and $\mathrm{K}^{+}$transport in erythrocytes as was demonstrated by Engelmann et al. (1990b, 1993). Sailaja et al. (2004) reported a reduction of cholesterol and phospholipid membrane content during maturation of human reticulocytes, whereas cholesterol-to-phospholipid ratio was increased in mature erythrocytes compared to reticulocytes. Moreover, fatty acid compositions of phosphatidylcholine and phosphatidylethanolamine as well as the rates of fatty acid esterification to these phospholipids were found to be changed progressively during erythrocyte in vivo aging. These changes were revealed by a comparison of "young" and "old" erythrocyte populations separated by density gradient centrifugation (Kunimoto et al. 1984).

The aim of our present study was to find a relationship between erythrocyte maturity, lipid composition of erythrocyte membranes and the activity of ion transporters in the rat. Density centrifugation was used to separate erythrocytes into fractions enriched with younger and older cells in control rats and in animals subjected to repeated hemorrhage in order to increase the fraction of immature cells in the circulating erythrocytes. In this study we compared immature erythrocytes of hemorrhaged rats with mature erythrocytes of control animals.

\section{Methods}

Animals

Eighteen male Wistar rats (Velaz, CR) aged three months were used in this study. Animals were housed under standard laboratory conditions (temperature $23 \pm 1{ }^{\circ} \mathrm{C}, 12$-h light/dark cycle) and maintained on tap water and standard rodent chow ST 1 ad libitum. One half of the rats (experimental group) was subjected to repeated hemorrhage blood loss $2 \mathrm{ml}$ per day for 6 consecutive days to enrich circulating erythrocytes with immature forms. On the day of the experiment, about $10 \mathrm{ml}$ of blood was withdrawn from the abdominal aorta and anticoagulated by $200 \mathrm{IU}$ of heparin (Léčiva, Prague, CR).

All procedures performed in experimental animals, which were approved by the Ethical Committee of the Institute of Physiology of the Czech Academy of Sciences, conform to the European Convention on Animal Protection.

\section{Isolation of immature and mature erythrocytes}

Hematocrit (15 min, hematocrit centrifuge 316, Unipan, Warsaw, Poland) and hemoglobin content (Merckotest Hemoglobin, Merck, Darmstadt, Germany) were determined from heparinized blood and used for calculation of mean cell hemoglobin content (MCHC, 
$\mathrm{mmol} / \mathrm{l} \mathrm{RBC}$ ). Thereafter blood was centrifuged (10 min, $2205 \mathrm{x} \mathrm{g}, 4^{\circ} \mathrm{C}$ ) and plasma and buffy coat were removed. Isolated red blood cells (RBC) from control and hemorrhaged rats were gently resuspended in isotonic choline chloride solution $(155 \mathrm{mmol} / \mathrm{l})$ and the immature $\mathrm{RBC}$ were separated by repeated centrifugation (10 min, $2205 \mathrm{x} \mathrm{g}, 4{ }^{\circ} \mathrm{C}$ ) from the mature cells. $50 \%$ suspensions of erythrocytes were prepared from the matured and immatured erythrocytes and used for subsequent determinations.

\section{Counting of reticulocytes}

Both whole blood and $50 \%$ suspension of erythrocytes were mixed with $2 \%$ brilliant cresyl blue and kept at room temperature for $15 \mathrm{~min}$. The number of reticulocytes was expressed per 1000 erythrocytes which were counted under $100 \mathrm{x}$ oil immersion.

\section{Determination of ion transport}

Ion transport parameters were measured in the $50 \%$ suspension of erythrocytes according to the protocol described in details by Bin Talib and Zicha (1992). Briefly, erythrocytes were washed three times with isotonic choline chloride solution $(155 \mathrm{mmol} / \mathrm{l})$ and hemolyzed by $6 \%$ n-butanol with $1 \%$ cesium chloride. Erythrocyte intracellular $\mathrm{Na}^{+}\left(\mathrm{Na}^{+}{ }_{\mathrm{i}}\right)$ content was determined using atomic absorption spectrophotometer (Solaar 969, Unicam, Cambridge, UK) and it was expressed in $\mathrm{mmol} / \mathrm{l} \mathrm{RBC}$. Ion transport mediated by the $\mathrm{Na}^{+}-\mathrm{K}^{+}$pump, $\mathrm{Na}^{+}-\mathrm{K}^{+}-2 \mathrm{Cl}^{-}$cotransport and cation leaks were determined in erythrocytes that were washed three times with saline medium (in mmol/l: $\mathrm{NaCl} 140$, glucose 5, morpholinepropanesulfonic acid 10, phosphoric acid 2.5, pH 7.4 at $\left.37^{\circ} \mathrm{C}, 310 \mathrm{mosmol} / \mathrm{l}\right)$. Washed erythrocytes were incubated in saline medium with $3.5 \mathrm{mmol} / 1 \mathrm{RbCl}$ for $30 \mathrm{~min}$ at $37^{\circ} \mathrm{C}$. Incubation media were nominally free of bicarbonate. $\mathrm{Rb}^{+}$was used as an analog of $\mathrm{K}^{+}$for its chemical and physical properties. Net $\mathrm{Na}^{+}$movements and unidirectional $\mathrm{Rb}^{+}$ fluxes were assessed at intracellular $\mathrm{Na}^{+}$and extracellular $\mathrm{Rb}^{+}\left(\mathrm{K}^{+}\right)$concentrations that were close to those found in vivo. Ouabain ( $5 \mathrm{mmol} / \mathrm{l}$, Serva, Heidelberg, Germany) and bumetanide (10 $\mu \mathrm{mol} / \mathrm{l}$, Leo Pharmaceutical Product, Ballerup, Denmark) were used to inhibit $\mathrm{Na}^{+}-\mathrm{K}^{+}$pump (ouabain-sensitive $\mathrm{Na}^{+}$net extrusion and ouabainsensitive $\mathrm{Rb}^{+}$uptake) and $\mathrm{Na}^{+}-\mathrm{K}^{+}-2 \mathrm{Cl}^{-}$cotransport (bumetanide-sensitive $\mathrm{Na}^{+}$net extrusion and bumetanidesensitive $\mathrm{Rb}^{+}$uptake), respectively. $\mathrm{Na}^{+}$leak and $\mathrm{Rb}^{+}$leak were defined as residual fluxes resistant to both ouabain and bumetanide. Transport rates mediated by the above mentioned transport systems were expressed in mmol/l $\mathrm{RBC} / \mathrm{h}$ (using mean cell hemoglobin content found in particular animals).

\section{Analysis of membrane lipids}

Erythrocytes in the $50 \%$ suspension were washed three times with $0.9 \% \mathrm{NaCl}$. Extraction of lipids was done according to Rose and Oklander (1965). Briefly, erythrocytes were lysed with distilled water for $30 \mathrm{~min}$. Isopropanol was added during continuous stirring. After $60 \mathrm{~min}$ with occasional mixing, distilled chloroform was added and mixed. At the end of another hour, the mixture of erythrocytes, water, isopropanol and chloroform $(1: 1: 11: 7, \mathrm{v} / \mathrm{v})$ was centrifuged at $785 \mathrm{x} \mathrm{g}$ for $15 \mathrm{~min}$ at $4{ }^{\circ} \mathrm{C}$. The extracts were divided and evaporated under $\mathrm{N}_{2}$ atmosphere. Dried extracts for the determination of the total phospholipids were dissolved in chloroform-methanol- $0.9 \% \mathrm{NaCl}$ mixture $(4: 2: 1, \mathrm{v} / \mathrm{v})$. Phospholipid phosphorus from lower organic phase was mineralized to inorganic phosphorus which was measured colorimetrically at $820 \mathrm{~nm}$ and expressed in $\mu \mathrm{mol}$ phosphorus/g RBC (Rouser et al. 1970). In the other samples of dried extract the total cholesterol was estimated by diagnostic set (Bio-La-Test CHOL 150, Lachema, Brno, CR) and expressed in $\mu \mathrm{mol} / \mathrm{g} \mathrm{RBC}$. Erythrocyte phospholipids were separated by twodimensional thin layer chromatography into the individual phospholipid classes: phosphatidylethanolamine (PE), phosphatidylcholine (PC), sphingomyelin (SM), phosphatidylinositol (PI) and phosphatidylserine (PS). Silica gel H (Merck, Darmstadt, Germany) as a slurry of $22.5 \mathrm{~g}$ in $62 \mathrm{ml}$ water containing 2.5 g magnon (Merck, Darmstadt, Germany) was spread in $0.25 \mathrm{~mm}$ layer with a spreader (Desaga, Heidelberg, Germany) on glass plates $(20 \times 20 \mathrm{~cm})$. Solvent mixtures were used according to the method of Rouser et al. (1970): chloroform-methanol-ammonia-water (70:25:4:1, $\mathrm{v} / \mathrm{v})$ and chloroform-methanol-acetone-acetic acid-water (70:12.5:17.5:10:4.5, v/v). Phospholipids were detected by the exposure of the plate to iodine vapor and the respective spots were scraped off. Phospholipid phosphorus was mineralized to inorganic phosphate, measured colorimetrically at $820 \mathrm{~nm}$ and expressed in $\mu$ mol phosphorus/g RBC.

\section{Statistical analysis}

Results were expressed as means \pm SEM and the statistical differences among experimental groups were 
evaluated by Student t-test. Linear correlation analysis was used to test the association between ion transport parameters and lipid components of RBC membrane.

\section{Results}

Hemorrhaged rats had significantly increased number of reticulocytes, reduced hematocrit and decreased mean cellular hemoglobin content in comparison with control rats (Fig. 1). The immature erythrocytes in the hemorrhaged group differed from the mature cells of control rats not only by higher reticulocyte incidence $(30.8 \pm 1.8$ vs. $1.4 \pm 0.2 \%, \mathrm{p}<0.001)$ and decreased MCHC (4.75 \pm 0.08 vs. $5.06 \pm 0.07 \mathrm{mmol} / 1$ RBC, $\mathrm{p}<0.01$ ) but also by the elevated activity of $\mathrm{Na}^{+}-\mathrm{K}^{+}$ pump (ouabain-sensitive $\mathrm{Na}^{+}$extrusion: $9.31 \pm 0.45$ vs. $\left.7.34 \pm 0.47 \mathrm{mmol} \mathrm{Na}{ }^{+} / 1 \mathrm{RBC} / \mathrm{h}, \mathrm{p}<0.01\right)$, reduced activity of $\mathrm{Na}^{+}-\mathrm{K}^{+}$cotransport (bumetanide-sensitive $\mathrm{Rb}^{+}$uptake) and increased bumetanide-resistant $\mathrm{Rb}^{+}$leak (Fig. 2), whereas bumetanide-resistant $\mathrm{Na}^{+}$leak was not enhanced signifi-cantly $\quad\left(8.87 \pm 0.63\right.$ vs. $\quad 7.68 \pm 0.71 \mathrm{mmol} \mathrm{Na}^{+} / 1$ $\mathrm{RBC} / \mathrm{h})$.
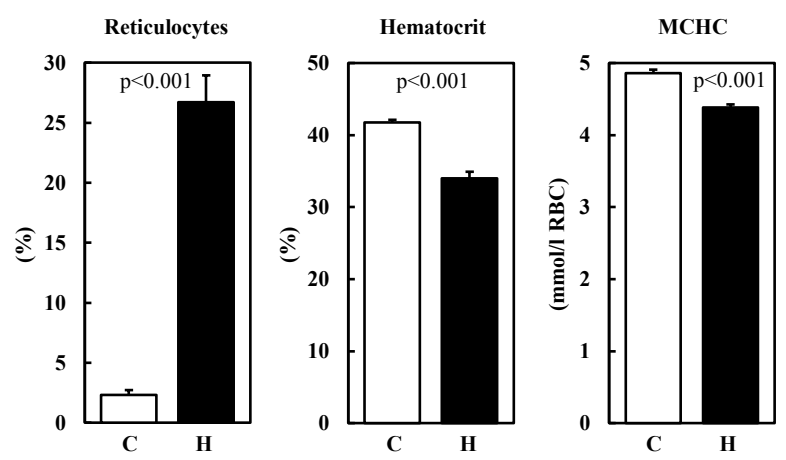

Fig. 1. Reticulocyte incidence, hematocrit and mean cell hemoglobin content $(\mathrm{MCHC})$ in control $(\mathrm{C})$ and hemorrhaged $(\mathrm{H})$ rats. $\mathrm{RBC}-$ red blood cells.
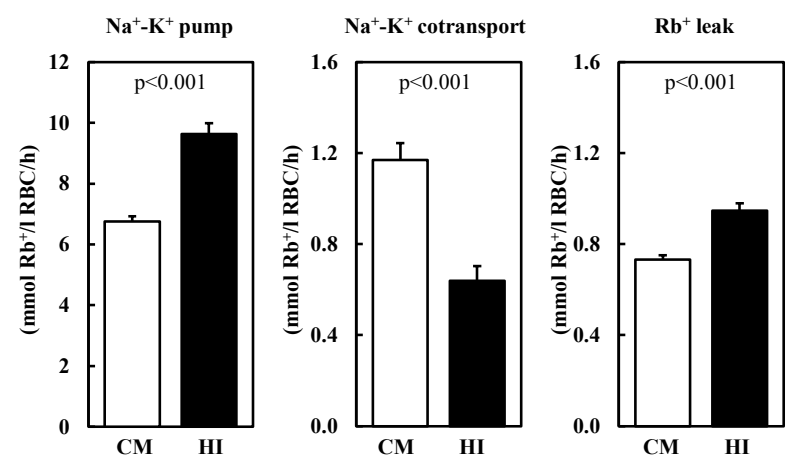

Fig. 2. Ion transport in mature erythrocytes of control rats (control-mature, CM) and immature erythrocytes of hemorrhaged rats (hemorrhaged-immature, $\mathrm{HI}$ ).
The differences in ion transport parameters were accompanied by unchanged concentrations of total cholesterol, higher total phospholipids and reduced cholesterol-to-phospholipids ratio in immature compared to mature erythrocytes (Fig. 3). However, no significant differences in the membrane content of particular phospholipid classes were found between immature and mature erythrocytes (Table 1).
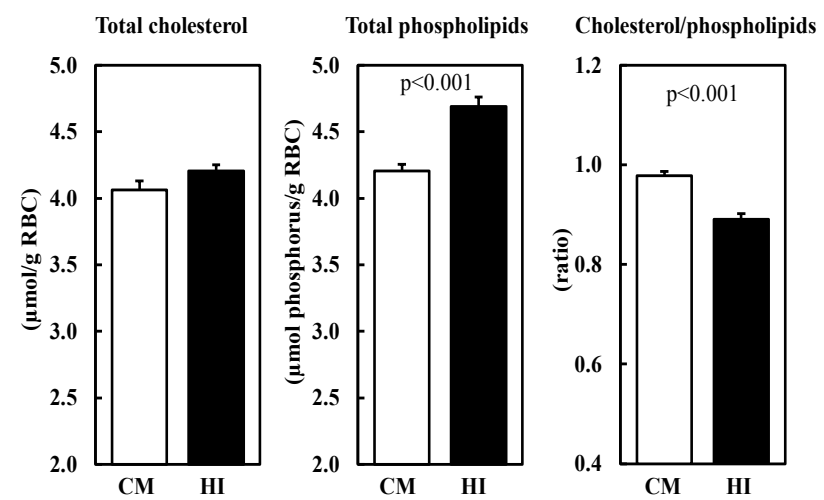

Fig. 3. Total cholesterol and phospholipids in mature erythrocytes of control rats (control-mature, CM) and immature erythrocytes of hemorrhaged rats (hemorrhaged-immature, $\mathrm{HI}$ ).

There were no significant correlations of ion transport parameters with membrane cholesterol content, but membrane content of total phospholipids correlated positively with ouabain-sensitive $\mathrm{Na}^{+}-\mathrm{K}^{+}$pump activity and negatively with bumetanide-sensitive $\mathrm{Na}^{+}-\mathrm{K}^{+}$ cotransport activity (Fig. 4). Membrane phospholipid content also correlated positively with ouabain- and bumetanide-resistant $\mathrm{Na}^{+}$leak and $\mathrm{Rb}^{+}$leak (Fig. 4). Phosphatidylserines were the only distinct phospholipid class which had the relationships to ion transport parameters similar to those reported above for total phospholipids (Fig. 5).

MCHC correlated highly significantly with cell $\mathrm{Na}^{+}$content $(\mathrm{r}=0.800, \mathrm{n}=33, \mathrm{p}<0.001)$ and it had negative relationships with membrane content of total phospholipids or phosphatidylserines $(\mathrm{r}=-0.362, \mathrm{n}=33$, $\mathrm{p}<0.05$ and $\mathrm{r}=-0.469, \mathrm{n}=33, \mathrm{p}<0.01$, respectively). There were significant negative correlations of MCHC with $\mathrm{Na}^{+}-\mathrm{K}^{+}$pump activity but positive correlations of MCHC with $\mathrm{Na}^{+}-\mathrm{K}^{+}$cotransport activity; negative relationship of $\mathrm{MCHC}$ with cation leaks was significant only for ouabain- and bumetanide-resistant $\mathrm{Rb}^{+}$leak (Fig. 6). 
Table 1. Distribution of particular phospholipid classes in mature erythrocytes of control rats (CM) and immature ones of hemorrhaged animals (HI).

\begin{tabular}{ccc|ccc}
\hline Phospholipids & $\begin{array}{c}\text { CM } \\
\text { Absolute values } \\
\text { ( } \begin{array}{c}\text { Mmol phosphorus/g RBC) } \\
\text { PI }\end{array}\end{array}$ & Phospholipids & $\begin{array}{c}\text { CM } \\
\text { Expressed as a percentage } \\
\text { of total phospholipids }\end{array}$ \\
\hline$P E$ & $0.80 \pm 0.02$ & $0.79 \pm 0.05$ & $P E$ & $26.0 \pm 1.2$ & $24.5 \pm 1.5$ \\
$P C$ & $1.61 \pm 0.06$ & $1.49 \pm 0.08$ & $P C$ & $52.8 \pm 3.1$ & $46.0 \pm 2.3$ \\
$S M$ & $0.35 \pm 0.03$ & $0.36 \pm 0.02$ & $S M$ & $10.4 \pm 0.6$ & $10.8 \pm 0.6$ \\
$P S$ & $0.31 \pm 0.02$ & $0.36 \pm 0.03$ & $P S$ & $9.9 \pm 0.8$ & $11.2 \pm 0.5$ \\
$P I$ & $0.03 \pm 0.01$ & $0.01 \pm 0.01$ & $P I$ & $0.7 \pm 0.2$ & $0.4 \pm 0.1$ \\
\hline
\end{tabular}

Values are means \pm SEM. PE - phosphatidylethanolamines, PC - phosphatidylcholines, SM - sphingomyelins, PS - phosphatidylserines, PI - phosphatidylinositols, RBC - red blood cells.
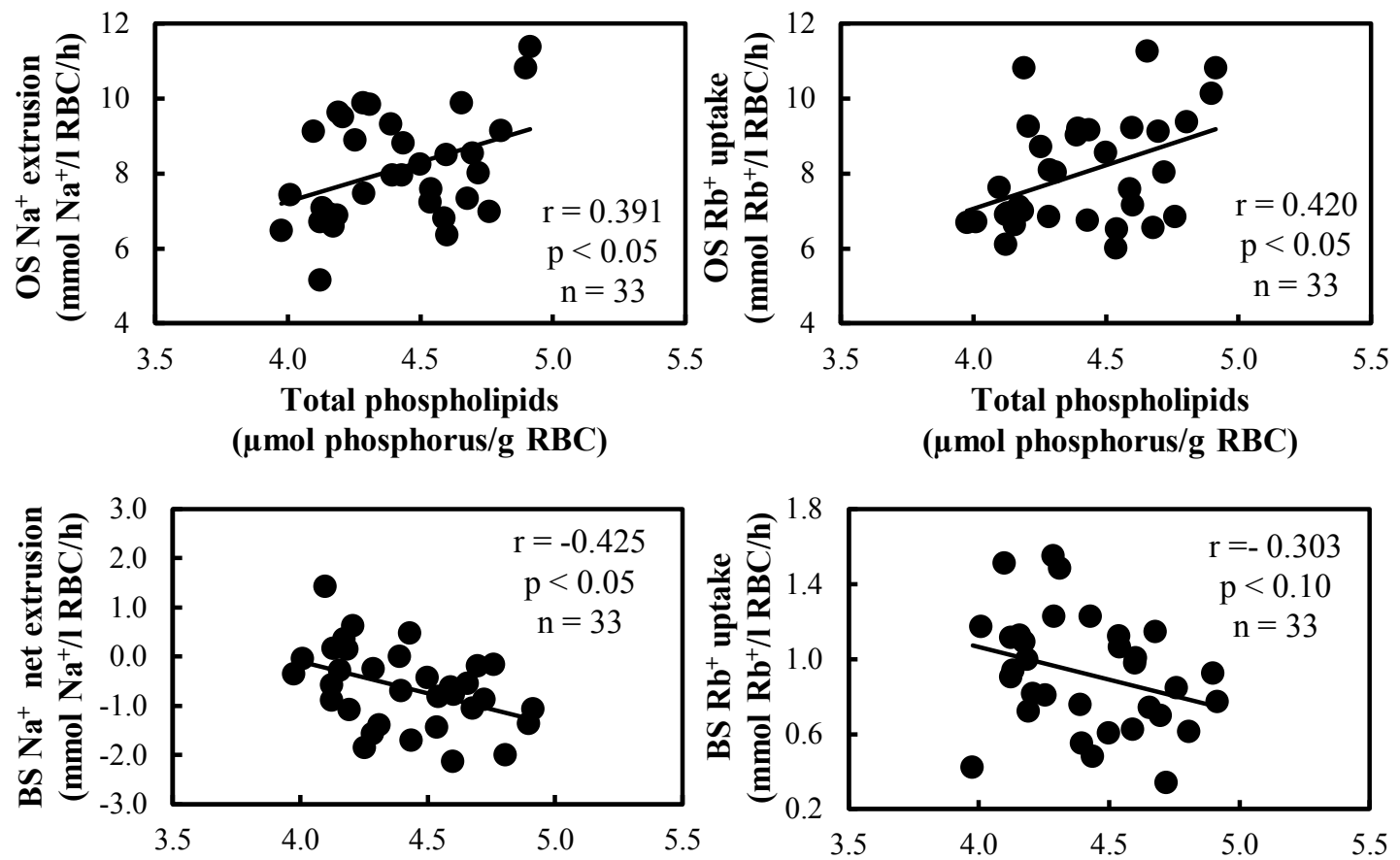

Total phospholipids ( $\mu$ mol phosphorus/g RBC)
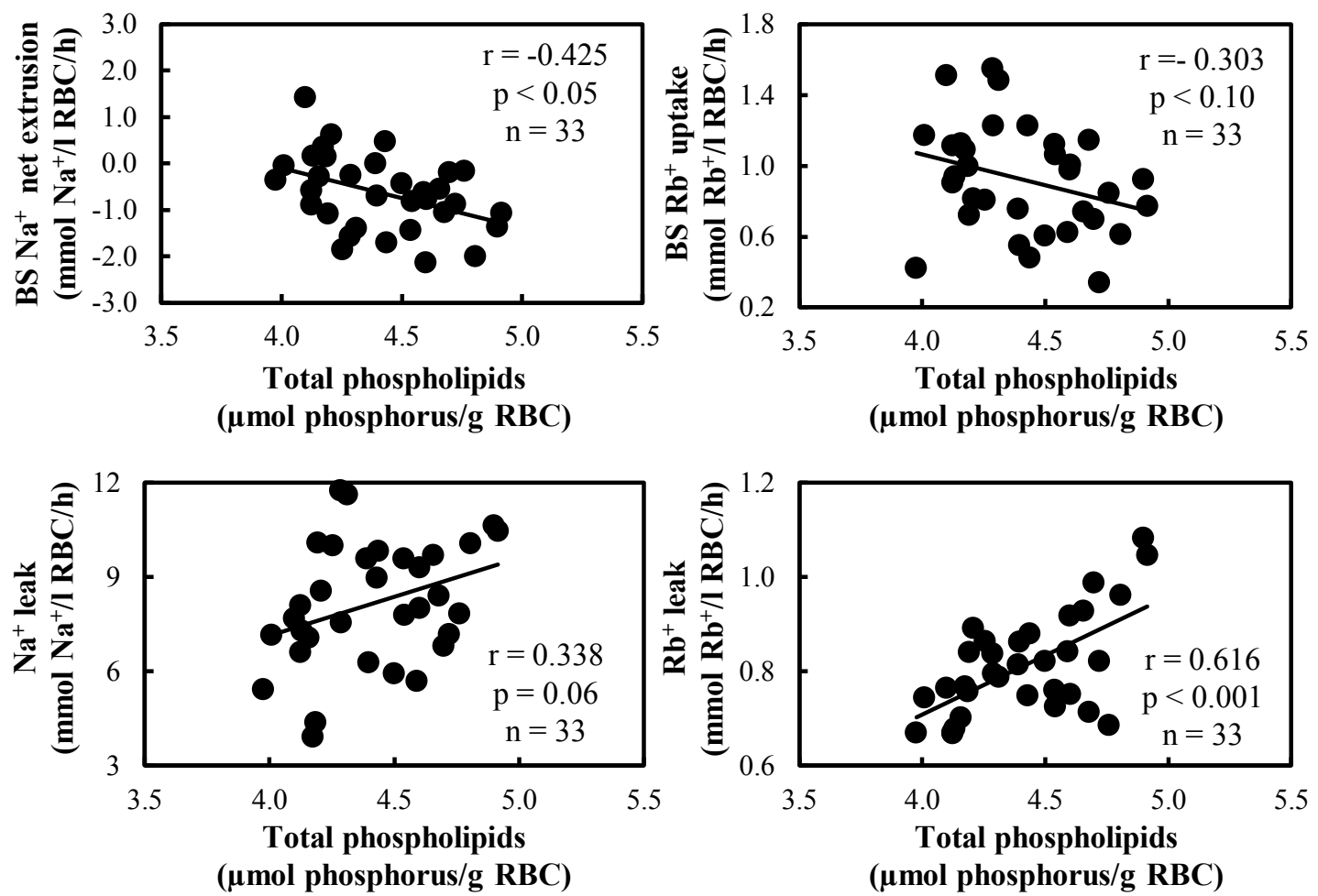

Fig. 4. Correlations of $\mathrm{Na}^{+}-\mathrm{K}^{+}$pump activity, $\mathrm{Na}^{+}-\mathrm{K}^{+}$cotransport activity and cation leaks with erythrocyte membrane content of total phospholipids in all studied erythrocyte populations. 

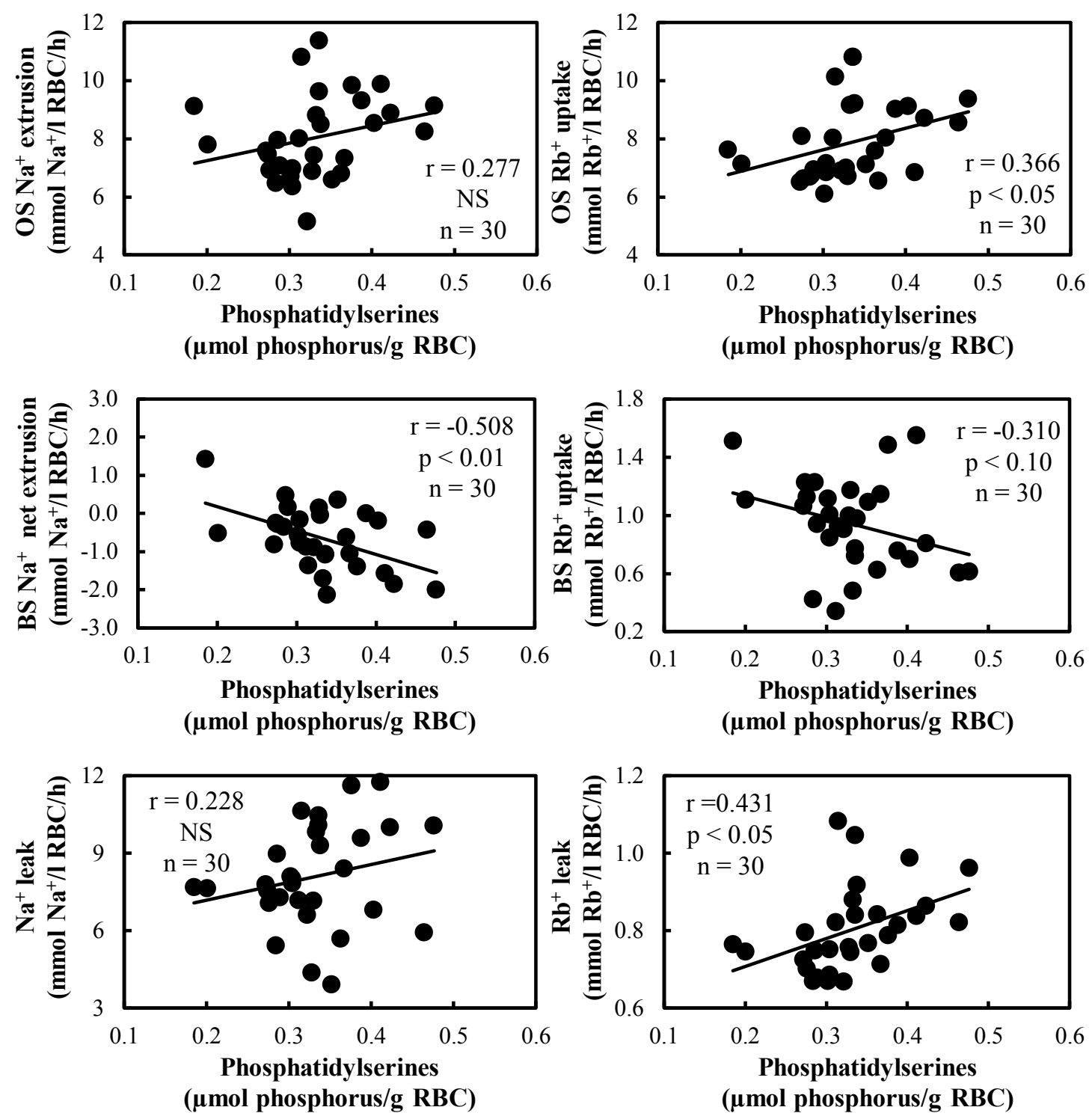

Fig. 5. Correlations of $\mathrm{Na}^{+}-\mathrm{K}^{+}$pump activity, $\mathrm{Na}^{+}-\mathrm{K}^{+}$cotransport activity and cation leaks with erythrocyte membrane content of phosphatidylserines in all studied erythrocyte populations.

\section{Discussion}

Erythrocyte maturation is closely associated with the changes of cell volume which is decreasing during the cell life. Therefore, a repeated centrifugation can be used to separate more dense mature and older erythrocytes from the lighter fraction containing younger and immature forms of erythrocytes. In both human and rat erythrocytes the cell volume plays a critical role in the control of $\mathrm{Na}^{+}-\mathrm{K}^{+}-2 \mathrm{Cl}^{-}$cotransport activity because cell shrinkage accompanying cell maturation/ageing, which is characterized by increased MCHC, is always associated with the enhanced activity of this cotransport to counteract these unfavorable cell volume change (Duhm and Göbel 1984a,b). In fact, if rat reticulocytes are exposed to hypertonic medium to induced cell shrinkage, their low activity of $\mathrm{Na}^{+}-\mathrm{K}^{+}-2 \mathrm{Cl}^{-}$cotransport is enhanced eight-fold, indicating the presence of expressed molecules of this transporter in the membrane of immature red blood cells (Mäirbaurl et al. 2000). This explains why in our experiments the mature erythrocytes display higher activity of bumetanide-sensitive $\mathrm{Na}^{+}-\mathrm{K}^{+}-2 \mathrm{Cl}^{-}$ cotransporter compared to immature ones. The reticulocytes or immature erythrocytes are characterized by higher cell volume which is controlled by another ion transporter $\mathrm{K}^{+}-\mathrm{Cl}^{-}$cotransport the activity of which is decreasing with cell maturation (Brugnara and Tosteson 1987, Canessa et al. 1987). 

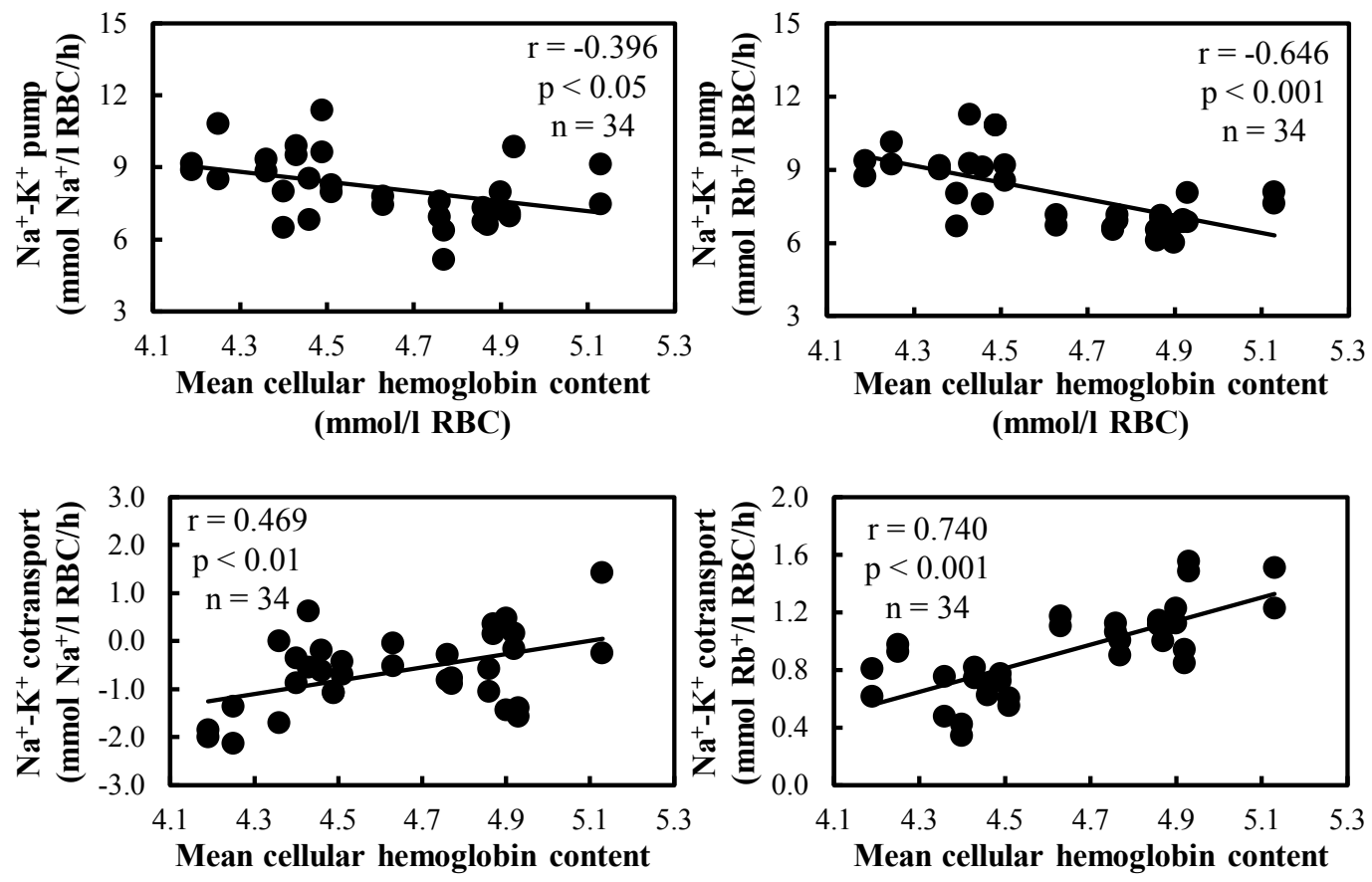

(mmol/l RBC)
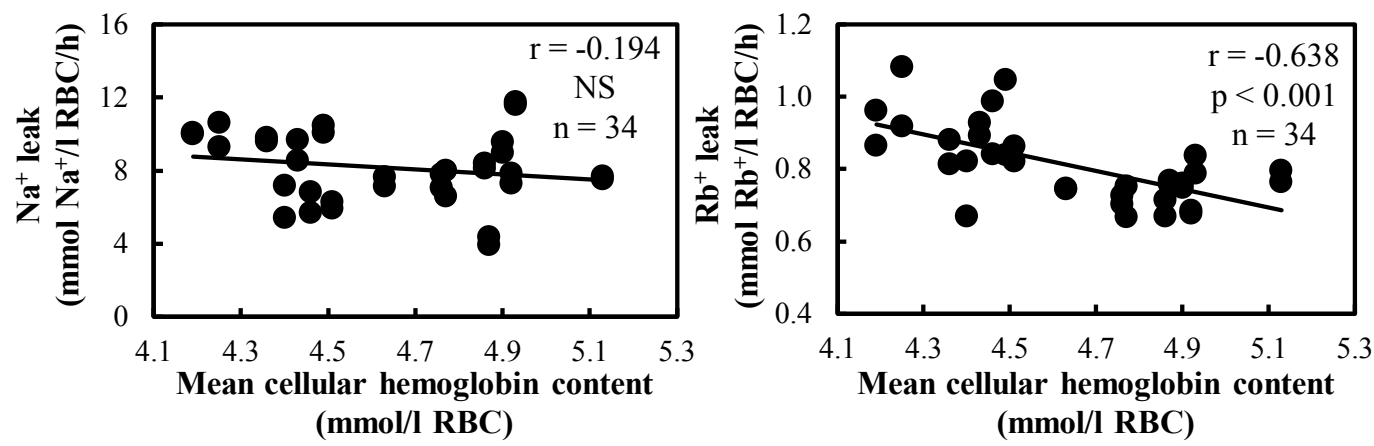

Fig. 6. Correlations of $\mathrm{Na}^{+}-\mathrm{K}^{+}$pump activity, $\mathrm{Na}^{+}-\mathrm{K}^{+}$cotransport activity and cation leaks with mean cell hemoglobin content in all studied erythrocyte populations.

$\mathrm{Na}^{+}-\mathrm{K}^{+}$pump activity is elevated in rat reticulocytes (Furukawa et al. 1981, Mäirbaurl et al. 2000 ) and it decreases during cell maturation both in vivo and in vitro. One of the reason for the enhanced $\mathrm{Na}^{+}-\mathrm{K}^{+}$ pump activity might be a functional demand to keep pace with augmented $\mathrm{Na}^{+}$leak (Mäirbaurl et al. 2000) due to a possible increase in the passive membrane permeability in reticulocytes. The mechanism by which the balance between enhanced $\mathrm{Na}^{+}$entry and $\mathrm{Na}^{+}$extrusion is reestablished in reticulocytes, is the increased number of $\mathrm{Na}^{+}-\mathrm{K}^{+}$pump sites on enlarged cell surface. Furukawa et al. (1981) reported three times greater number of ouabain biding sites per unit volume of rat reticulocytes compared to mature erythrocytes. Our data also indicate increased $\mathrm{Na}^{+}-\mathrm{K}^{+}$pump activity and enhanced $\mathrm{Rb}^{+}$leak in immature rat erythrocytes as compared to mature ones.

The above mentioned ion transport changes can also reflect the age-dependent changes of membrane lipid composition. Engelmann et al. (1993b) demonstrated that $\mathrm{Na}^{+}-\mathrm{Li}^{+}$countertransport is accelerated in hyperlipidemic patients and maximal activity of this transporter is positively related to red cell phosphatidylcholine but negatively to sphingomyelin membrane content. The important changes of ion transport mediated by $\mathrm{Na}^{+}-\mathrm{Li}^{+}$ countertransport or furosemide-sensitive cotransporter(s) might be induced by fatty acid exchange in phosphatidylcholine of erythrocyte membrane (Engelmann et al. 1990b). Molecular species of membrane phosphatidylcholine and phosphatidylethanolamine contribute to the interindividual variability of $\mathrm{Na}^{+}-\mathrm{Li}^{+}$countertransport in normal human population (Engelmann et al. 1993a) as well as in patients with hyperlipidemias (Engelmann et al. 1992).

Our study revealed certain changes in plasma membrane lipid composition which occur during erythrocyte maturation. As far as the membrane 
cholesterol or phospholipid content is concerned, our present data from rat erythrocytes are in a good agreement with the changes disclosed during maturation of human reticulocytes (Sailaja et al. 2004).

Although we failed to find significant differences in particular phospholipid classes between immature and mature erythrocytes, the measured ion transport parameters had significant relationships to total membrane phospholipid content and this was also true for phosphatidylserines. It should be noted that there was a complex interrelationship between mean cell hemoglobin content, membrane phospholipids and ion transport which reflected the process of rat erythrocyte maturation.

Our previous study performed in salt hypertensive Dahl rats (Vokurková et al. 2005) demonstrated similar dependence of particular ion transport parameters on mean cell hemoglobin content as our present study, suggesting the important contribution of immature cells to ion transport abnormalities reported in salt hypertensive animals. Less clear is the contribution of phospholipid alterations because phosphatidylserines had a major impact in this study, whereas sphingomyelins were important in our previous study of Vokurková et al. (2005).

Our data suggest that certain abnormalities of ion transport and membrane lipid composition detected in erythrocytes of hypertensive animals might be caused by higher incidence of immature cells hemolytic anemia in salt hypertensive Dahl rats is a typical example (Luckhaus et al. 1982, Zicha and Duhm 1990). Another important factor contributing to ion transport alterations in hypertension might be related to the coincidence of various forms of dyslipidemia that might affect membrane lipid composition, membrane fluidity and the lipid environment of ion transporters located in the cell membrane (for details see Zicha et al. 1999).

In conclusion, it is evident that the maturation of circulating rat erythrocytes is accompanied by characteristic changes in the activity of principle ion transporters (such as $\mathrm{Na}^{+}-\mathrm{K}^{+}$pump and $\mathrm{Na}^{+}-\mathrm{K}^{+}-2 \mathrm{Cl}^{-}$ cotransporter) and passive membrane permeability as well as by the changes of membrane content of total cholesterol and total phospholipids.

\section{Conflict of Interest}

There is no conflict of interest.

\section{Acknowledgements}

The authors would like to thank to Marie Schützová, Alena Petrová, Iva Nahodilová, Markéta Krupková and Natálie Hánová for their excellent technical assistance. Valuable comments of Ivana Vaněčková were appreciated. This work was partially supported by the research grants 304/12/0259 (Czech Science Foundation) and 15-25396A (Ministry of Health CR) as well as by the research project RVO:67985823 (Institute of Physiology of the CAS).

\section{References}

BIN TALIB HK, ZICHA J: Red cell sodium in DOCA-salt hypertension: a Brattleboro study. Life Sci 50: 1021-1030, 1992.

BLOSTEIN R, DRAPEAU P, BENDEROFF S, WEIGENSBERG AM: Changes in $\mathrm{Na}^{+}$-ATPase and Na,K-pump during maturation of sheep reticulocytes. Can J Biochem Cell Biol 61: 23-28, 1983.

BRUGNARA C, TOSTESON DC: Cell volume, $\mathrm{K}^{+}$transport and cell density in human erythrocytes. Am J Physiol 252: C269-C276, 1987.

BRUGNARA C, KRUSKAL MS, JOHNSTONE RM: Membrane properties of erythrocytes in subjects undergoing multiple blood donations with or without recombinant erythropoietin. Br J Haematol 84: 118-130, 1993.

CANESSA M, FABRY ME, BLUMENFELD N, NAGEL RL: Volume-stimulated, $\mathrm{Cl}^{-}$-dependent $\mathrm{K}^{+}$efflux is highly expressed in young human red cells containing normal hemoglobin or HbS. J Membr Biol 97: 97-105, 1987.

DUHM J, GÖBEL BO: $\mathrm{Na}^{+}-\mathrm{K}^{+}$transport and volume of rat erythrocytes under $\mathrm{K}^{+}$deficiency. Am J Physiol 246: C20-C29, 1984a.

DUHM J, GÖBEL BO: Role of furosemide-sensitive $\mathrm{Na}^{+} / \mathrm{K}^{+}$transport system in determning the steady-state $\mathrm{Na}^{+}$and $\mathrm{K}^{+}$content and volume of human erythrocytes in vitro and in vivo. J Membr Biol 77: 243-254, $1984 \mathrm{~b}$.

ENGELMANN B, GREVERS G, JANKA HU, DUHM J: Alterations in $\mathrm{Na}^{+}, \mathrm{K}^{+}$and $\mathrm{Ca}^{2+}$ transport in erythrocytes of patients with carcinomas of the head and neck: possible role of mild anaemia and cell age. Clin Sci (Lond) 78: 315-320, 1990a. 
ENGELMANN B, OP DEN KAMP JA, ROELOFSEN B: Replacement of molecular species of phosphatidylcholine: influence on erythrocyte Na transport. Am J Physiol 258: C682-C691, 1990b.

ENGELMANN B, STREICH S, SCHÖNTHIER UM, RICHTER WO, DUHM J: Changes of membrane phospholipid composition of human erythrocytes in hyperlipidemias. I. Increased phosphatidylcholine and reduced sphingomyelin in patients with elevated levels of triacylglycerol-rich lipoproteins. Biochim Biophys Acta 1165: 32-37, 1992.

ENGELMANN B, DUHM J, SCHÖNTHIER UM, STREICH S, OP DEN KAMP JA, ROELOFSEN B: Molecular species of membrane phospholipids containing arachidonic acid and linoleic acid contribute to the interindividual variability of red blood cell $\mathrm{Na}^{+}-\mathrm{Li}^{+}$countertransport: in vivo and in vitro evidence. $J M e m b r$ Biol 133: 99-106, 1993a.

ENGELMANN B, DUHM J, SCHÖNTHIER UM, STREICH S: Relations of sodium-lithium countertransport kinetics to plasma and red cell membrane phospholipids in hyperlipidemia. Atherosclerosis 99: 151-163, $1993 \mathrm{~b}$.

ETZION Z, LEW VL, BOOKCHIN RM: $\mathrm{K}\left({ }^{86} \mathrm{Rb}\right)$ transport heterogeneity in the low-density fraction of sickle cell anemia red blood cells. Am J Physiol 271: C1111-C1121, 1996.

FURUKAWA H, BILEZIKIAN JP, LOEB JN: Potassium fluxes in the rat reticulocyte. Ouabain sensitivity and changes in the maturation. Biochim Biophys Acta 649: 625-632, 1981.

HENTSCHEL WM, WU LL, TOBIN GO, ANSTALL HB, SMITH JB, WILLIAMS RR, ASH KO: Erythrocyte cation transport activities as a function of cell age. Clin Chim Acta 157: 33-43, 1986.

IHRIG I, SCHÖNHEIT C, HÄUBNER W, BERNHARDT I: Characterisation of the potassium influx in rat erythrocytes. Gen Physiol Biophys 11: 377-388, 1992.

KUNIMOTO M, KAYA K, MIURA T: Composition and metabolism of fatty acids in phospholipids of densityseparated red cells of rats. Lipids 19: 443-448, 1984.

LAUF PK, ZEIDLER RB, KIM HD: Pig reticulocytes. V. Development of $\mathrm{Rb}^{+}$influx during in vitro maturation. $J$ Cell Physiol 121: 284-290, 1984.

LUCKHAUS G, GARTHOFF B, KAZDA S: Prevention of hypertensive vasculopathy by nifedipine salt-loaded Dahl rats. Arzneimittel-forschung 32: 1421-1425, 1982.

MÄIRBAURL H, SCHULZ S, HOFFMAN JF: Cation transport and cell volume changes in maturing rat reticulocytes. Am J Physiol Cell Physiol 279: C1621-C1630, 2000.

MATCHKOV VV, KUDRYAVTSEVA O, AALKJAER C: Intracellular $\mathrm{Ca}^{2+}$ signalling and phenotype of vascular smooth muscle cells. Basic Clin Pharmacol Toxicol 110: 42-48, 2012.

MISÁRKOVÁ E, BEHULIAK M, BENCZE M, ZICHA J: Excitation-contraction coupling and excitation-transcription coupling in blood vessels: their possible interactions in hypertensive vascular remodeling. Physiol Res 65: in press, 2016.

QUARMYNE MO, RISINGER M, LINKUGEL A, FRAZIER A, JOINER C: Volume regulation and KCl cotransport in reticulocyte populations of sickle and normal red blood cells. Blood Cells Mol Dis 47: 95-99, 2011.

ROSE HG, OKLANDER M: Improved procedure for extraction of lipids from human erythrocytes. J Lipid Res 6: 428-431, 1965.

ROUSER G, FLEISCHER S, YAMAMOTO A: Two dimensional then layer chromatographic separation of polar lipids and determination of phospholipids by phosphorus analysis of spots. Lipids 5: 494-496, 1970.

SAILAJA YR, BASKAR R, SRINIVAS RAO CS, SARALAKUMARI D: Membrane lipids and protein-bound carbohydrates status during the maturation of reticulocytes to erythrocytes in type 2 diabetics. Clin Chim Acta 341: 185-192, 2004.

VOKURKOVÁ M, NOVÁKOVÁ M, DOBEŠOVÁ Z, KUNEŠ J, ZICHA J: Relationships between membrane lipids and ion transport in red blood cells of Dahl rat. Life Sci 77: 1452-1464, 2005.

ZICHA J, DUHM J: Kinetics of $\mathrm{Na}^{+}$and $\mathrm{K}^{+}$transport in red cells of Dahl rats: effects of age and salt. Hypertension 15: 612-627, 1990.

ZICHA J, KUNEŠ J, DEVYNCK MA: Abnormalities of membrane function and lipid metabolism in hypertension: a review. Am J Hypertens 12: 315-331, 1999. 